\title{
Determinan Motivasi Kerja Tenaga Kesehatan Pegawai Pemerintah Non Pegawai Negeri (PPNPN) di Rumah Sakit Angkatan Laut Dr Mintohardjo
}

\author{
Hari Raharja ${ }^{1}$, Istiana Kusumastuti ${ }^{2}$ \\ 1,2Program Studi Kesehatan Masyarakat Sekolah Tinggi Ilmu Kesehatan Indonesia Maju \\ Jln. Harapan Nomor 50, Lenteng Agung - Jakarta Selatan 12610 \\ Email : mynameisraharja@gmail.com, ${ }^{2}$ istianaku31@gmail.com
}

Editor: -

Hak Cipta:

(C2021 Artikel ini memiliki akses terbuka dan dapat didistribusikan berdasarkan ketentuan Lisensi Atribusi Creative Commons, yang memungkinkan penggunaan, distribusi, dan reproduksi yang tidak dibatasi dalam media apa pun, asalkan nama penulis dan sumber asli disertakan. Karya ini dilisensikan di bawah Lisensi Creative Commons Attribution Share Alike $\mathbf{4 . 0}$ Internasional.

\section{A B S T R A C T}

Introduction: Raising and maintaining work motivation is absolutely done by every organization is a management of human resources (HR), including HR for health workers in conducting health services.

Objectives: The purpose of the study was to determine the relationship of the work environment, compensation and work training with work motivation of PPNPN health workers in Dr.Mintohardjo Rumkital in 2020.

Method: The design of this study was quantitative crosssectional, with a sample of 105 respondents. Data analysis was performed univariately and bivariately with Spearman Correlation's Analysis.

Result: The results show there is a relationship between the work environment ( $p$-value $=0.000$ and $r=0.628$ ), compensation (p-value $=0.000$ and $r=0.427$ ), and job training ( $p$-value $=0.000$ and $r=0.504$ ) with work motivation of PPNPN health workers in Dr.Mintohardjo Rumkital in 2020.

Conclution: Dr.Mintohardjo's Rumkital can increase the motivation of PPNPN health workers by increasing the safety of the work environment, providing compensation tailored to the workload and adjusting the type of work training to the problems faced by health workers so that health services can be improved and reducing the turnover rate of Dr.Mintohardjo's PPNPN Rumkital health workers.

Keyword: Work Environment, Compensation, Work Training, Work Motivation, PPNPN. 


\section{Pendahuluan}

Diketahui bahwa motivasi adalah ikatan kerjasama antara bagian yang berkerja bersama bagian yang memperkejakanya yang dibebankan, setiap individu pekerja pasti memiliki sesuatu untuk menjadi tanggung jawab mereka wajib dipenuhi dengan melaksanakan program kegiatan, tindakan atau usaha, sehingga segalanya yang menjadi kewajiban dapat dicapai sepadan dengan pengharapan yang dikehendaki. Motivasi seorang pekerja penting sebagai suatu daya dorong untuk digunakan oleh seseorang supaya bisa berusaha serta agar tercapainya pemenuhan kepuasan dalam hidup. ${ }^{1}$

Suatu dorongan yang selalu diarahkan organisasi ini diharapkan mampu dijaga secara berkelanjutan agar terus memberikan efek hasil positif bagi suatu organisasi. ${ }^{2}$ Selain mengharapkan timbulnya semangat motivasi murni supaya bisa muncul disetiap individu pekerja, motivasi sendiri dapat didapatkan di luar individu dari seorang yang sedang berkerja. Motivasi didapatkan dengan mengacu suatu proses dimana, pekerja di suatu kelompok selalu diberikan suatu energi atau dorongan supaya bisa diarahkan kepada suatu tujuan sebuah organisasi mudah didapatkan.

Pada umumnya sebuah perusahaan menginginkan pegawainya memiliki kemampuan, kecakapan dan keterampilan untuk mengerjakan tugas-tugasnya. Kemudian ada hal-hal di setiap individu pekerja ketika melaksanakan pekerjaannya adalah dorongan serta tekad kuat seorang individu supaya melakukan tugas tugasnya sunguh sungguh, supaya tujuanya dapat diraih dengan memuaskan maka ketika melaksanakan kewajiban kerjaanya. Seluruh skil yang dimiliki, kecakapan dan keterampilan seorang pekerja, tidak akan bisa menghasilkan kerjaan dengan hasil optimal untuk perusahaan bila semangat seorang pekerja di dirinya ketika beraktivitas kerja tidak tercurahkan maksimal. ${ }^{3}$

Dampak dari hilangnya suatu semangat dalam sebuah pekerjaan seorang pegawai menyebabkan akibat buruk terhadap setiap organisasi. Hilangnya motivasi kerja berakibat pada menurunnya gairah semangat berkerja serta kepuasan terhadap output tugas yang dilaksanakan seorang pekerja sulit tercapai. Menurunnya kualitas keterbelangsungan suatu pekerjaan suatu perusahaan mengakibatkan penurunan disiplin serta mepengaruhi loyalitas pegawai terhadap perusahaan tempat mereka melakukan pekerjaannya. ${ }^{3}$ Peningkatan motivasi pegawai dapat mengakibatkan munculnya kreativitas dan meningkatnya keikutsertaan pegawai membereskan suatu pekerjaan yang diemban, selain dapat mempertinggi kewajiban bahkan terjadinya efisiensi dalam penggunaan peralatan serta bahan baku kerja, juga terciptanya keterikatan kerja menjadi baik. ${ }^{4}$

Diketahui bahwa dari referensi penelitian yang pernah dilaksanakan tentang lingkungan kerja dan motivasi seorang pekerja ternyata didapatkan hasil ada hubungan yang begitu signifikan. Dapat diartikan lingkungan kerja yang menyenangkan mampu memotivasi pegawai untuk selalu bekerja dengan baik. Situasi lingkungan kerja fisik serta lingkungan kerja non fisik dalam lingkungan kerja diharapkan selalu terjaga dengan baik, oleh sebab itu pegawai bekerja selalu termotivasi dalam upaya menyelesaikan pekerjaan untuk kebutuhan pengakuan, kebutuhan menjalin hubungan kerja dan kebutuhan mampu berkembang terpenuhi. ${ }^{5}$

Penelitian lain juga menjelaskan bahwa Lingkungan Kerja mempunyai pengaruh yang kuat mepengaruhi terciptanya motivasi kerja secara optimal dilihat dari nilai hasil pengujian korelasi. Oleh sebab itu jika lingkungan kerja dengan motivasi kerja menghasilkan hubungan positif, yang berarti bahwa adanya kemampuan variabel lingkungan kerja mepengaruhi sebuah motivasi individu saat melakukan pekerjaannya. ${ }^{6}$ Penelitian lainnya menyimpulkan bahwa lingkungan kerja fisik dan lingkungan kerja non fisik bisa berpengaruh pada motivasi pegawai dalam melakukan pekerjaannya. ${ }^{7}$ Sedangkan menurut penelitian lainnya lagi bahwa variabel kompensasi berpengaruh positif secara 
signifikan terhadap motivasi kerja pagawai dimana kompensasi kerja bila dinaikkan dapat menaikkan motivasi pegawai. ${ }^{8,9}$

Hal lainnya yang mepengaruhi motivasi kerja pada para pegawai ialah pelatihan kerja. Berdasarkan penelitian menjelaskan suatu pelatihan kerja berpengaruh dalam meningkatkan motivasi kerja pegawai, semakin sesuai pelatihan kerja yang diberikan untuk para pegawai mengakibatkan motivasi kerja pegawai dapat semakin meningkat. ${ }^{10}$ selain itu peneliti lain menyatakan pelatihan tidak berpengaruh banyak terhadap motivasi kerja, hal ini terjadi jika materi selama pelatihan kurang dipergunakan dalam praktik nyata pekerjaan serta metode instruktur dalam menyampaikan materi pelatihan sulit dimengerti. ${ }^{11}$

Setiap organisasi memiliki cara unik tersendiri dalam pembinaan terhadap motivasi kerja sumber daya manusia yang dimilikinya, hal ini tergantung tujuan atau pencapaian suatu target dari sebuah perusahaan. Salah satu organisasi yang memiliki kompleksitas tinggi dalam melakukan pembinaan sumber daya manusianya adalah Rumah Sakit. ${ }^{12}$ Dapat dipastikan disetiap rumah sakit memiliki pengelolaan manajemen sumber daya manusia yang terbagi menjadi dua bagian besar terdiri dari tenaga kesehatan serta bukan bagian dari tim medis. Dapat diartikan bahwa pegawai Rumah Sakit tersebut terdiri dalam berbagai macam disiplin ilmu yaitu disiplin ilmu medis, para medis, penunjang medis, administrasi dan lain-lain. Para pengelola sumber daya manusia pastinya memiliki permasalahan yang rutin dihadapi dalam mengelola organisasinya yaitu proses turnover pegawai. Turnover atau pergantian pegawai dalam suatu organisasi adalah fenomena penting dalam kelangsungan organisasi. ${ }^{4}$ Turnover akan menjadi masalah karena akan menyita waktu organisasi melakukan rekrutan pegawai baru.

Menurut data yang diberitakan oleh work institute mengenai survey tingkat kebahagiaan pegawai Indonesia, terdapat 71 dari 100 orang jumlah pegawai menyatakan bahagia pada tugas yang sedang dilakukan ketika sekarang oleh seorang dalam melaksanakan pekerjaannya. Terdapat beberapa hal yang mampu membuat pegawai bahagia terhadap pekerjaannya yakni letak tempat bekerja, rekan kerja dan nama baik perusahaan tempat kerja. Sedangkan masalah utama penyebab pegawai merasa tidak bahagia dalam pekerjaannya yakni kurannya pengembangan pada karier pegawai, kepemimpinan dilingkungan pekerjaan dan pelatihan kerja yang diberikan perusahaan tempat bekerja.

Secara keseluruhan pegawai pada usia 31-35 tahun memiliki ketidakpuasan terhadap pekerjaannya diakibatkan nilai gaji dan fasilitas yang didapatkan dari tempat kerja. Perusahaan skala besar dengan pegawai sekitar 1000 orang, cenderung lebih bahagia bila dibandingkan perusahaan dengan pegawai dibawah 50 orang. Sementara pegawai yang paling bahagia dilihat berdasarkan spesialistik dibidangnya adalah pegawai dibidang keuangan pimpinan manager dan pengelola perangkat keras elektronik. Pada bidang lainnya pegawai yang merasa tidak bahagia berasalkan dari penjual barang teknis, disain grafis dan dokter. ${ }^{13}$ Adanya suatu nilai ketidakpuasan dapat penyebab turnover dan memiliki akibat pada banyak aspek, diantaranya ketidakpuasan pada sistem manajemen perusahaan, keadaan pekerjaannya, pemantauan seorang bos, upah, reward, naik jabatan serta interaksi lebih luas di seluruh dunia. ${ }^{4}$

Mengacu pada data tenaga sumber daya manusia yang dimiliki Rumah Sakit TNI Angkatan Laut (Rumkital) Dr.Mintohardjo, jumlah pegawai terdiri dari tenaga pegawai kesehatan dan tenaga pegawai non kesehatan dengan unsur militer, Aparatur Sipil Negara (ASN) serta Pegawai Pemerintahan Non Pegawai Negeri (PPNPN) yang menjadi SDM nya. Hal unik terjadi pada PPNPN dimana jumlah pegawai PPNPN tercatat sekitar 14\% dari keseluruhan pegawai atau mencakup $24 \%$ jumlah tenaga 


\section{Public Health Education

kesehatan Rumkital Dr.Montohardjo. Selain itu tingkat turnover pegawai PPNPN dari tahun $2017 \mathrm{~s} / \mathrm{d}$ 2019 antara 3-7\% dari keseluruhan PPNPN yang dihitung setiap bulannya. ${ }^{14}$

Data di Rumkital Dr.Mintohardjo ternyata pemberian motivasi sangat berperan dalam meningkatkan semangat kerja pegawai terutama mengetahui seberapa besar hubungan antara ketiga variabel yaitu lingkungan kerja, kompensasi dan kepuasan kerja terhadap motivasi kerja pegawai dalam bekerja terutamanya tenaga kesehatan PPNPN Rumkital Dr.Mintohardjo, sehingga peneliti akhir tertarik dengan judul Hubungan Lingkungan kerja, Kompensasi dan Kepuasan Kerja dengan Motivasi kerja tenaga kesehatan pegawai pemerintah non pegawai negeri sipil di Rumkital Dr.Mintohardjo. Tujuan yang ingin didapat dari penelitian yang dilaksanakan ini ialah agar bisa diketahui apakah terdapat hubungan diantara variabel lingkungan kerja, kompensasi serta pelatihan kerja terhadap motivasi dalam bekerja tenaga kesehatan PPNPN di Rumkital Dr. Mintohardjo tahun 2020.

\section{Metode}

Cross Sectional merupakan desain yang dilakukan pada penelitian ini, yang artinya semua varibel dilakukan penelitian di waktu yang sama dengan diteliti berbarengan. Cross sectional artinya proses pengumpulan dan pengukuran data variabel bebas dan variabel terikat dilakukan 1 (satu) kali yang bertujuan untuk mempelajari dinamika korelasi antara variabel bebas dan variabel terikat. ${ }^{15}$ Populasi adalah jumlah keseluruhan semua anggota yang mempunyai karakteristik tertentu sesuai dengan penelitian. ${ }^{17}$ Dalam penelitian ini yang dijadikan populasi adalah seluruh pegawai tenaga kesehatan PPNPN yang bertugas melayani pasien di Rumkital Dr.Mintohardjo data pegawai yang dipakai adalah sebanyak 140 pekerja yang merupakan pekerja PPNPN di bulan Februari tahun 2020.

Sampel penelitian adalah objek yang diteliti dan dianggap mewakili seluruh populasi dan tenik pengambilan sampel dalam penelitian ini dengan menggunakan Disproportionate Statified Random Sampling, dimana digunakan untuk menentukan jumlah sampel bila populasi berstrata tetapi kurang proporsi tenaga kesehatan PPNPN. ${ }^{16}$ adapun sampel dalam penelitian ini setelah dihitung maka di dapatkan jumlah sampel 105 pegawai dan tambahan sampel sebagai cadangan pengisian kuesioner $5 \%$ pegawai tenaga kesehatan PPNPN yang bekerja di Rumah Sakit Dr.Mintohardjo.

Ketika ingin mengambil sampel maka peneliti menggunakan kriteria inklusi dan ekslusi. Adapun pengertian kriteria inklusi merupakan ciri maupun kriteria yang harus ada dan bisa terpenuhi dari setiap orang di populasi maka bisa dipakai sebagai sampel, adapun kriteria inklusi dalam penelitian ini adalah Pegawai tenaga kesehatan PPNPN yang bekerja lebih dari 3 bulan keatas di Rumah Sakit Dr.Mintohardjo dan Pegawai Rumkital Dr.Mintohardjo yang bekerja sebagai tenaga kesehatan PPNPN yang sedang bertugas dan bersedia menjadi responden. ${ }^{15}$ Sedangkan untuk setiap orang dipopulasi yang bukan memenuhi ciri maupun kriteria maka itu disebut sebagai kriterian ekslusi, adapun kriteria ekslusi dalam penelitian ini adalah Pegawai tenaga kesehatan PPNPN yang tidak bisa hadir pada saat penelitian di Rumah Sakit Dr.Mintohardjo dan pegawai tenaga kesehatan PPNPN yang tidak bersedia mengisi kuesioner di Rumah Sakit Dr.Mintohardjo. ${ }^{15}$

Data primer adalah data untuk keperluan dirinya sendiri yaitu dengan cara melakukan wawancara dan menyebarkan kuesioner responden. Sedangkan data sekunder data yang diperoleh tidak langsung seperti dokumen-dokumen resmi yang berupa sejumlah data dan profil dari Rumah Sakit Dr.Mintohardjo. Agar seorang peneliti mengetahui apakah alat ukur yang digunakan dalam sebuah penelitian benar dalam mengukur, dalam penelitian ini menggunakan kuisoner maka bisa dilakukan dengan uji validitas. Untuk mengetahui apaah kuesioner yang kita susun tersebut mampu mengukur apa yang hendak kita ukur, maka perlu diuji dengan uji korelasi antara skor (nilai) dari per butir soal di 


\section{Journal of

kuisoner. ${ }^{15}$ Setelah melakukan uji validitas maka untuk mengetahui bisa dipercaya atau tidaknya alat ukur jika digunakan akan selalu konsisten maupun selalu sama bila dilakukan pengujian berapakalipun maka bisa dilakukan menggunakan uji reliabilitas. ${ }^{15}$

Pada penelitian ini anasis yang digunakan berupa analisis univariat serta analisis bivariat. Supaya dapat menjabarkan seluruh variabel yang diteleti satu persatu menggunakan tabel distrubusi frekuensi maka yang di gunakan adalah analisis univariat. Analisis variabel univariat dalam penelitian ini adalah variabel independen lingkugan kerja, kompensasi, dan pelatihan kerja, serta variabel dependen motivasi kerja. Sedangkan untuk mengetahui apakah terdapat hubungan antara variabel independen dengan variabel dependen maka dilakukan analisis bivariat.

Hipotesis yang di uji dikatakan memiliki hubungan ( $p$-value) atau berarti jika nilai Sig. (2tailed) hasil perhitungan lebih kecil dari nilai tarap kepercayaan 0,05 atau 0,01. Namun sebaliknya ketika nilai Sig. (2-tailed) hasil perhitungan lebih besar dari nilai tarap kepercayaan 0,05 atau 0,01 maka dapat disimpulkan tidak ada hubungan yang siginfikan. ${ }^{16}$

Analisis rank spearman merupakan analisis yang digunakan dalam penelitiian ini agar bisa tau berpa keeratan hubungan diantara kedua variabel serta bisa tau arah hubungan yang terjadi, dalam menentukan kekuatan hubungan korelasi bisa berpendoman pada nilai koefisien korelasi dengan ketentuan nilai :

Tabel 1. Nilai Rentan Hubungan Korelasi (r)

\begin{tabular}{cc}
\hline Nilai Korelasi & Hubungan \\
\hline 0 & Tidak Ada Korelasi \\
\hline$>0,0-0,25$ & Korelasi Lemah \\
\hline$>0,25-0,50$ & Korelasi sedang \\
\hline$>0,50-0,75$ & Korelasi Kuat \\
\hline$>0,75-0,99$ & Korelasi Sangat Kuat \\
\hline 1 & Korelasi Sempurna \\
\hline
\end{tabular}

Hasil

Tabel 2. Distribusi Frekuensi Lingkungan Kerja, Kompensasi, Pelatihan Kerja, dan Motivasi Kerja Tenaga Kesehatan Pegawai Pemerintahan NonPegawai Negeri Di Rumkital Dr.Mintohardjo.

\begin{tabular}{lcc}
\hline \multicolumn{1}{c}{ Variabel } & N & \% \\
\hline Motivasi Kerja & & 92,4 \\
\hline Kuat & 97 & 7,6 \\
\hline Sedang & 8 & 0,0 \\
\hline Lemah & 0 & 48,6 \\
\hline Lingkungan Kerja & & 51,4 \\
\hline Baik & 51 & \\
\hline$\quad$ Kurang Baik & 54 & 49,5 \\
\hline Kompensasi & & 50,5 \\
\hline$\quad$ Baik & 52 & \\
\hline$\quad 53$ & 40,0 \\
\hline Pelatihan Kerja & 53 & 60,0 \\
\hline$\quad$ Baik & 42 &
\end{tabular}


Berdasarkan tabel 2 diatas dari 105 responden yang diteliti di Rumkital Dr.Mintohardjo, diketahui 97 responden atau $(92,4 \%)$ pada klasifikasi motivasi kerja kuat, sedangkan 8 responden atau (7,6\%) pada klasifikasi motivasi kerja lemah, sedangkan untuk motivasi kerja rendah dipenelitian ini nihil atau bisa disebut tidak terdapat. Lalu untuk lingkungan kerja diketahui bahwa 51 responden atau $(48,6 \%)$ memiliki penilaian baik pada lingkungan kerja dan 54 responden atau $(51,4 \%)$ memiliki penilaian dilingkungan kerjanya kurang baik. Sedangkan untuk variabel kompensasi diketahui 52 responden atau (49,5\%) memiliki penilaian baik pada kompensasi, dan 53 responden atau $(50,5 \%)$ memiliki penilaian di variabel kompensasi kurang baik. Dan untuk variabel pelatihan kerja diketahui 42 responden atau $(40,0 \%)$ memiliki penilaian baik terhadap pelatihan kerja, sedangkan 63 responden atau $(60,0 \%)$ memiliki penilaian kurang baik terhadap pelatihan kerja.

Analisis bivariat pada penelitian ini dilakukan untuk mengetahui apakah terdapat hubungan antara variabel independen dengan variabel dependen dan mengetahui sejauh mana keeratan hubunganya, oleh karena itu pada penelitian ini menggunakan uji korelasi rank spearman. Adapun hasil yang didaptkan dari ketiga variabel independen (lingkungan kerja, kompensasi, serta pelatihan kerja) dikaitkan dengan variabel dependen (motivasi kerja) para tenaga kesehatan PPNP di Rumkital Dr.Mintohardjo disajikan dengan tabel dan dijelaskan secara deskriptif adapun koeisien korelasi mengacu pada tebel nilai koelasi (tabel.1), sedangkan antara variabel yang diteliti dikatakan terdapat hubungan jika nilai alpa lebih jika dari nilai alfa yang telah ditentukan yaitu $p$-value $<0,05$ maka dapat ditari kesimpulan terdapat hubungan.

Berdasarkan hasil uji korelasi Rank Spearman (Tabel 3), diperoleh hasil berupa besaran alpha ( $p$-value) dari ketiga variabel independen dengan variabel dependen dengan hasil nilai $p$-value 0,000. Nilai alpha tersebut bernilai lebih kecil dari taraf alpha yang ditetapkan ( $p$ value $=0,000<\alpha=0,05$ ), maka diketahui bahwa terdapat hubungan antara variabel independen (lingkungan kerja, kompensasi, serta pelatihan kerja) terhadap variabel dependen (motivasi kerja tenaga kesehatan PPNPN) di Rumkital Dr.Mintohardjo tahun 2020.

Tabel 3. Hubungan lingkungan kerja, kompensasi dan pelatihan kerja dengan motivasi kerja responden tenaga kesehatan PPNPN Rumkital Dr.Mintohardjo ( $\mathrm{n}=105)$

\begin{tabular}{lcll}
\hline Variabel Independen & $\begin{array}{c}\text { Nilai Korelasi } \\
(\boldsymbol{r})\end{array}$ & $\boldsymbol{p}$-value & $\begin{array}{l}\text { Variabel Dependen } \\
\text { (Motivasi Kerja) }\end{array}$ \\
\hline Lingkungan Kerja & 0.628 & 0.000 & Kuat dan Nyata \\
\hline Kompensasi & 0.427 & 0.000 & Sedang dan Nyata \\
\hline Pelatihan Kerja & 0.504 & 0.000 & Kuat dan Nyata \\
\hline
\end{tabular}

Selanjutnya untuk hasil analsis korelasi Rank Spearman pada variabel lingkungan kerja (Tabel 3) memiliki hubungan yang searah serta kuat antara lingkungan kerja dan motivasi kerja dengan hasil $r=0,628$, oleh karena itu jika lingkungann kerja baik maka motivasi pekerja juga akan baik bahkan lingkungan kerja sangat kuat pengaruhnya terhadap motivasi seorang pekerja

Lalu pada uji Rank Spearman pada variabel kompensasi (Tabel 3) diketahui bahwa keeratan hubungan pada varibel kompensasi dengan motivasi kerja tenaga kesehatan PPNP yaitu searah serta keeratanya sedang dengan nilai koefisien korelasi $r=0,427$. Oleh karena itu jika besaran kompensasi yang diterima para pekerja kesehatan PPNPN semakin tinggi maka begitu juga dengan motivasi para pekerjapun dapat meningkat di taraf sedang. 
Kemudian untuk variabel terakhir dalam penilitian ini yaitu variabel pelatihan kerja (Tabel 3) diketahui bahwa dari hasil uji Rank Spearman terdapat hubungan yang searah dan kuat antara pelatihan kerja terhadap motivasi kerja tenaga kesehatan PPNPN dengan nilai koefesien korelasi $r=0,504$. Oleh karena itu pekerja yang menerima pelatihan dalam berkerja dapat meningkatkan motivasinya dalam berkerja yang dengan dampak yang kuat

\section{Pembahasan}

\section{Hubungan Lingkungan Kerja dengan Motivasi Kerja Tenaga Kesehatan PPNPN Rumkital Dr. Mintohardjo}

Hasil korelasi rank spearman variabel lingkungan kerja dengan motivasi kerja terhadap 105 responden tenaga kesehatan PPNPN Rumkital Dr.Mintohardjo dengan nilai $p$-value $=0.000$ lebih kecil dari pada nilai alpha $(0,05)$ dan diperoleh nilai koefisien korelasi diketahui nilai $r=0.628$, sehingga dapat diartikan bahwa $\mathrm{H} 0$ ditolak dan $\mathrm{H} 1$ diterima. Oleh karena itu adanya hubungan yang kuat dan menuju arah positif di kedua variabel lingkungan kerja terhadap motivasi kerja. Hal ini dapat diartikan bahwa lingkungan kerja yang nyaman dan bersih dapat meningkatkan motivasi kerja pegawai dalam melakukan pekerjaannya.

Begitupun dari hasil penelitian yang dilakukan oleh Krisnawanto, dengan hasil penelitian menunjukan terdapat hubungan yang bersifat positif di variabel lingkungan kerja dengan motivasi pekerja, ketika keadaan lingkungan kerja baik begitupun motivasi para pekerja juga akan baik juga. Hasil uji korelasi Pearson diperoleh besaran nilai koefisien korelasi $r=0,612$ dengan $p$-value $=0,000$ $(\mathrm{pv}<0,01)$ dengan makna terdapat hubungan positif yang sangat signifikan antara lingkungan dengan motivasi kerja. Pegawai yang tidak termotivasi walaupun memiliki kemampuan akan menolak untuk bekerja dengan keras. Hal ini karena motivasi kerja adalah kemauan kerja pegawai yang timbul diakibatkan adanya dorongan dalam pribadi pegawai yang dipengaruhi faktor lingkungan kerja. ${ }^{17}$

Penelitian lain disampaikan juga oleh Ingsiyah dan Heni bahwa kondisi lingkungan kerja berpengaruh terhadap motivasi kerja pegawai. Penelitian ini memilki tujuan utama untuk mampu mengukur adanya pengaruh lingkungan kerja dengan motivasi kerja pegawai. Lingkungan kerja berpengaruh dengan koefisien regresi 0.948 dan nilai signifikan pada taraf 0.001 . Semakin baik suatu lingkungan kerja mengakibatkan kenaikan tingkat motivasi kerja pegawai dalam menyelesaikan tugas yang dihadapi. ${ }^{7}$ Menurut Arep dan Tanjung, mengemukakan lingkungan kerja yang baik dapat bermanfaat untuk menciptakan gairah bekerja, sehingga meningkat prestasi dan produktivitas bekerja. Manfaat lainnya yang dapat diperoleh dengan bekerja beserta orang -orang yang termotivasi adalah pekerjaan dapat diselesaikan lebih cepat dan tepat, artinya pekerjaan diselesaikan sesuai standar yang benar dan dalam skala waktu yang telah ditentukan. ${ }^{18}$

Peneliti berasumsi bahwasannya tenaga kesehatan dalam berkerja memerlukan situasi lingkungan kerja yang baik secara fisik dan non fisik. Lingkungan kerja fisik dapat meningkatkan motivasi kerja pegawai terutama dalam hal kenyamanan dan keamanan bekerja, sedangkan menjaga hubungan baik antar pegawai diketahui bisa meningkatnya motivasi para pekerja saat melaksanakan pekerjaannya. Motivasi kerja pagawai dapat ditingkatkan terutama dalam hal keamanan di tempat kerja dengan memastikan fasilitas dan perlengkapan alat kerja yang digunakan pegawai diyakinkan selalu berada pada kondisi baik dan aman. Peningkatan lain untuk menaikkan motivasi kerja pegawai melalui lingkungan kerja adalah dengan kecepatan respon terhadap permintaan perbaikan kerusakan atau penggantian alat kerja yang digunakan tenaga kesehatan, sehingga tenaga kesehatan dalam melakukan tugasnya dapat tenang memiliki kepastian terhadap hasil pekerjaan yang dicapai. 


\section{Hubungan Kompensasi Dengan Motivasi Kerja Tenaga Kesehatan PPNPN Rumkital Dr.Mintohardjo}

Hasil korelasi Rank spearman variabel kompensasi dengan motivasi kerja terhadap 105 responden tenaga kesehatan PPNPN Rumkital Dr.Mintohardjo diperoleh nilai koefisien korelasi diketahui nilai $r=0.427$ dengan nilai $p$-value $=0.000$ lebih kecil dari pada nilai alpha $(0,05)$ dengan nilai signifikan lebih kecil dari pada nilai alpha $(0,05)$ sehingga dapat diartikan $\mathrm{H} 0$ ditolak dan $\mathrm{H} 1$ diterima dan adanya hubungan yang sedang dan menuju arah positif antara variabel kompensasi dengan motivasi kerja. Hal ini dapat diartikan bahwa peningkatan pemberian kompensasi yang diberikan oleh pihak Rumkital Dr.Mintohardjo mampu menaikkan motivasi kerja tenaga kesehatan PPNPN.

Mengacu terhadap penelitian Sembiring dan Haganta dengan kesimpulan yang diperoleh, bahwa kompensasi memiliki pengaruh signifikan dengan motivasi kerja para pegawai. Ketika sistem pemberian kompensasi yang diberikan kepada pegawai pada besaran yang baik, akan mepengaruhi motivasi kerja pegawai dalam melakukan setiap kegiatan di perusahaan guna membantu terhadap pencapaian tujuan perusahaan. Koefisien regresi kompensasi sebesar 0,442 dan berkoefisien positif yang menyatakan bahwa setiap penambahan $1 \%$ nilai kompensasi, maka nilai motivasi kerja bertambah sebesar 0,442 oleh karena itu kompenasi sangat mempengaruhi motivasi. ${ }^{19}$

Hasil penelitian Laminingrum dan Anny menjabarkan bahwa adanya kontribusi besar dari kompensasi dengan munculnya motivasi kerja pegawai. dari $t$ tabel yaitu, 9,355 $>1,673$, maka dapat disimpulkan bahwa adanya pengaruh kompensasi terhadap motivasi kerja pada pegawai. Kondisi kompensasi yang didapatkan pegawai saat ini sudah berada pada nilai baik, maka pegawai dituntut mampu meningkatkan motivasi kerja. ${ }^{20}$

Peneliti berasumsi bahwasannya tingkat motivasi kerja dapat ditingkatkan melalui meningkatkan besaran kompensasi yang diberikan kepada pegawai. Salah satu caranya dengan menaikan besaran gaji pokok yang disesuaikan dengan pekerjaan yang dilakukan oleh tiap-tiap bagian tenaga kesehatan. Selain itu hal yang dapat meningkatkan motivasi kerja tenaga kesehatan PPNPN dari variabel kompensasi adalah dengan memberikan uang insentif yang lebih besar dan pemberian kompensasi secara tepat waktu kepada tenaga kesehatan PPNPN.

\section{Hubungan Pelatihan Kerja dengan Motivasi Kerja Tenaga Kesehatan PPNPN Rumkital Dr.Mintohardjo}

Hasil korelasi rank spearman variabel pelatihan kerja dengan motivasi kerja terhadap 105 responden tenaga kesehatan PPNPN Rumkital Dr.Mintohardjo diperoleh nilai koefisien korelasi diketahui nilai $r=0,504$ dengan nilai $p$-value $=0,000$ lebih kecil dari nilai alpha $(0,05)$ dengan nilai korelasi sebesar 0.504, sehingga dapat dipastikan H0 ditolak dan H1 diterima serta adanya hubungan yang kuat antara variabel lingkungan kerja dengan motivasi kerja menuju arah positif. Hal ini dapat diartikan bahwa peningkatan pelaksanaan pelatihan kerja yang diberikan oleh pihak rumak sakit dapat meningkatkan motivasi kerja tenaga kesehatan PPNPN. Pada penelitian Leonu dan Paulus menyimpulkan bahwa pengaruh variabel pelatihan terhadap variabel Motivasi menunjukkan nilai koefisien sebesar $0,491 .^{21}$

Menurut Cherrngton dalam Ansory dan Indrasari, Pelatihan di tempat kerja ialah salah satu pilihan yang paling mudah untuk dilakukan, bahwasannya pelatihan dianggap perlu jika dalam sebuah organisasi mempunyai permasalahan yang selalu berkaitan dengan pekerjaannya terutama dalam penentuan suatu pilihan cara dalam mengatasi permasalahan tersebut. ${ }^{4}$ 
Begitupun menurut penelitian Darmawan dan Yuyun dalam kesimpulannya mampu menunjukkan adanya pengaruh positif secara signifikan antara variabel pelatihan dengan motivasi kerja. Ini artinya pelatihan yang diukur melalui enam indikator yaitu: instruktur, peserta, materi, metode, tujuan, dan sasaran berpengaruh positif dan signifikan terhadap motivasi kerja pegawai. Pelatihan yang diberikan oleh pihak manajemen bermanfaat secara langsung sehingga berdampak positif dan signifikan terhadap motivasi kerja pegawai. ${ }^{22}$

Peneliti berasumsi bahwasannya dalam upaya meningkatkan motivasi kerja melalui pelatihan kerja di Rumkital Dr.Mintohardjo lebih mengutamakan pelatihan yang dapat meningkatkan atau menyelesaikan permasalahan yang terjadi seperti pelatihan penanganan penyakit terkini yaitu Corona Virus Disease 2019 (Covid-19) dan atau pelatihan alat kesehatan yang berhubungan langsung dalam pekerjaan masing - masing tenaga kesehatan. Hal lain yang menjadi perlu diperhatikah dalam melaksanakan pelatihan kerja adalah waktu pelaksanaan pelatihan kerja yang tidak mengganggu waktu kerja serta pemberian kegiatan pelatihan dilaksanakan dengan cara semenarik mungkin.

\section{Kesimpulan}

Terdapat hubungan disetiap derteminan motivasi kerja dengan hasil hubungan signifikan pada taraf kuat dan positif pada variabel lingkungan kerja dan pelatihan kerja serta hubungan signifikan pada taraf sedang dan positif pada variabel kompensasi dengan motivasi kerja tenaga kesehatan PPNPN di Rumkital Dr.Mintohardjo tahun 2020.

Dalam melakukan upaya peningkatan motivasi kerja tenaga kesehatan PPNPN hendaknya pimpinan beserta staf Rumkital Dr.Mintohardjo Jakarta dimulai dengan melakukan peningkatan lingkungan kerja, pelatihan kerja dan kompensasi. Peningkatkan lingkungan kerja dilakukan dengan upaya mempercepat proses perbaikan kerusakan alat kesehatan dan atau pengadaan alat kesehatan baru pengganti yang mampu dipakai dalam pemberian pelayanan kesehatan. Meningkatkan motivasi kerja melalui pelatihan kerja dilakukan dengan memberikan pelatihan-pelatihan perkembangan penyakit terkini seperti penanganan kasus Corona Virus Disease 2019 (COVID-19), pemakaian alat pelindung diri dan atau dengan pelatihan alat kesehatan yang berhubungan langsung dalam pekerjaan masing masing tenaga kesehatan. Sementara melalui kompensasi dalam upaya menjaga motivasi kerja pegawai adalah dengan meningkatkan besaran gaji dan insentif yang diberikan kepada tenaga kesehatan PPNPN.

\section{Konflik Kepentingan}

\section{Ucapan Terima Kasih}

\section{Pendanaan}

\section{References}

1. Undang-Undang RI. Republik Indonesia Nomor 36 Tahun 2009 Tentang Kesehatan. Jakarta: UU RI: 2009.

2. Undang-Undang Republik Indonesia Nomor 36 Tahun 2014 tentang tenaga Kesehatan. Dipetik Mei 06, 2016, dari: www.kemenkopmk.go.id/content/uu- nomor-36-tahun-2014.

3. Undang-Undang RI. Nomor 44 Tahun 2009 tentang Rumah Sakit. Jakarta: Undang-Undang RI; 2009.

4. Rahmawati. Penerapan Standar Keselamatan Dan Kesehatan Kerja. 2017.

5. Anies. Penyakit Akibat Kerja. Jakarta: Alexmedia Komputindo; 2005.

6. Depkes RI. Sistem Kesehatan Nasional. Jakarta: Depkes RI; 2009. 


\section{Journal of

7. Martina. Studi Kecelakaan Kerja Pada Petugas RS Elim Rantepao Dan RSUD Lakipada Makale Kabupaten Tana Toraja.Jurnal.Kesehatan Dan Keselamatan Kerja FKM Universitas Hasanudin Makassar.

8. Iwan MR. Analisis Risiko Kesehatan Dan Keselamatan Kerja (K3) Pada Perawat; 2018. WHO. Organization WH. A global brief on Hypertension: silent killer, global public health crises (World Health Day 2013). Geneva: WHO; 2013.

9. Sugiyono. Metode Penelitian Kuantitatif Kualitataif Dan Kombinasi (Mixed Methods). Bandung: Alfabeta; 2016.

10. Sujarweni. Metode Penelitian: Lengkap, Praktis Dan Mudah Dipahami. Yogyakarta: Pustaka Baru Press; 2004.

11. Moleong. Metode Penelitian Kualitatif. Bandung: Remaja Rosdakarya; 2009.

12. Hamidi. Metode Penelitian Kualitatif. Malang. UMM Prsess; 2010.

13. Wilujeng IK dkk. Manajemen Risiko Keselamatan Dan Kesehatan Kerja (K3) Di Rumah Sakit Jiwa Grhasia D.I. Yogyakarta; 2019.

14. Novie EM. Penerapan Sistem Manajemen K3RS Rumah Sakit Imanuel Bandung. Jurnal Kesehatan Kartika; 2007.

15. Nurfitriani S. Penerapan Standar Kesehatan Dan Keselamatan Kerja Rumah Sakit (K3RS) RSUD Ajappange Soppeng; 2012.

16. Sri Eka Dewi FS. Kurangi Pencemaran, Limbah B3 'Iron Slag' Diolah Jadi Batu Bata Ramah Lingkungan Tahun 2018.

17. Ramli S. Petunjuk Praktis Manajemen Kebakaran Fire Management. Jakarta: Dian Rakyat; 2010.

18. Kuntjoro AP. Pelayanan Kesehatan rumah sakit; 2018.

19. Sugiart. Pedoman Pengelolaan Peralatan Kesehatan Direktorat Bina Pelayanan Penunjang Medik Dan Sarana Kesehatan; 2015.

20. Talati dkk. Studi Kualitatif Kesiapsiagaan Tim Komite Bencana Rumah Sakit Pku Muhammadiyah Bantul Dalam Menghadapi Bencana Vol. 2, No. 1, April 2018, Pp. 8-15 $\underline{\text { Http://Journal.Stikessuryaglobal.ac.id. }}$ 